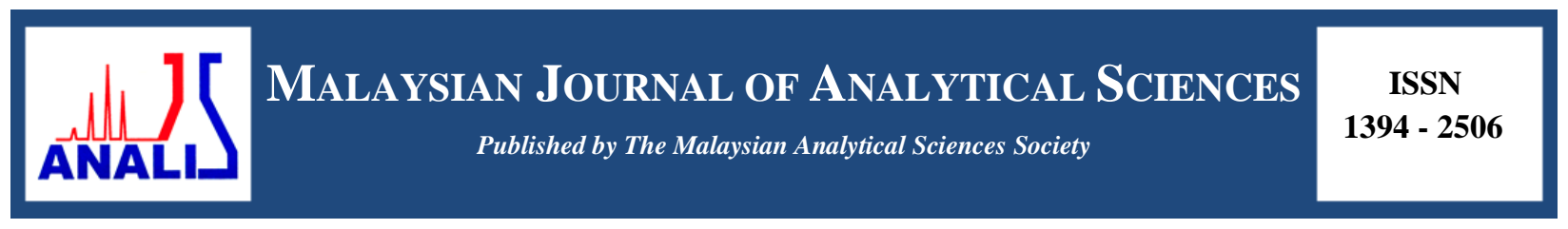

\title{
EFFECT OF PROCESS PARAMETERS ON THE SYNTHESIS OF POLYPYRROLE BY THE TAGUCHI METHOD
}

\author{
(Kesan Pembolehubah Proses Terhadap Sintesis Polipirola Menggunakan Kaedah Taguchi) \\ Rika Sri Utami ${ }^{1}$, Ifa Puspasari ${ }^{1}$, Loh Kee Shyuan ${ }^{1 *}$, Abu Bakar Mohamed ${ }^{1,2}$, Sagir Alva ${ }^{3}$ \\ ${ }^{1}$ Fuel Cell Institute \\ ${ }^{2}$ Department of Chemical and Process Engineering, Faculty of Engineering and Built Environment \\ Universiti Kebangsaan Malaysia, 43600 UKM Bangi, Selangor, Malaysia \\ ${ }^{3}$ Mechanical Engineering Department, Engineering Faculty, \\ Mercu Buana University, 11650 Jakarta, Indonesia \\ *Corresponding author: ksloh@ukm.edu.my
}

Received: 5 February 2016; Accepted: 22 April 2016

\begin{abstract}
Polypyrrole is a conductive polymer that is widely used in electrochemical applications. To identify the effects of different parameters on the synthesis of polypyrrole, an experimental design based on an orthogonal array $\mathrm{L}_{9}\left(3^{4}\right)$ proposed by Taguchi was applied. The parameters investigated were the oxidant type, molar ratio of oxidant: pyrrole, reaction time and dopant concentration, whereas the response variables observed were the yield, particle size and conductivity. Field Emission Scanning Electron Microscope (FESEM) characterization was used to study the morphology characteristics of the polypyrrole particles. Based on the signal-to-noise (S/N) ratio and the results of analysis of variance (ANOVA), the molar ratio of oxidant: pyrrole and the oxidant type significantly affected the yield and conductivity of the synthesized polypyrrole particles.
\end{abstract}

Keywords: design of experiment, conductive polymer, yield, particle size, conductivity

\begin{abstract}
Abstrak
Polipirola merupakan polimer konduktif yang digunakan secara meluas dalam aplikasi elektrokimia. Bagi tujuan mengenal pasti kesan-kesan parameter yang berbeza pada sintesis polipirola, reka bentuk eksperimen berdasarkan ortogon $\mathrm{L}_{9}\left(3^{4}\right)$ yang dicadangkan oleh Taguchi telah digunakan. Parameter yang dikaji ialah jenis oksidan, nisbah molar oksidan: pirola, masa tindak balas dan kepekatan pendopan, manakala pemboleh ubah sambutan yang diperhatikan adalah jumlah hasil, saiz zarah dan kekonduksian. Pencirian FESEM telah digunakan untuk mengkaji morfologi zarah polipirola. Berdasarkan nisbah isyarat-hingar $(\mathrm{S} / \mathrm{N})$ dan hasil analisis varians (ANOVA), nisbah molar oksidan: pirola dan jenis oksidan memberi kesan yang ketara kepada hasil dan kekonduksian dari sintesis polipirola.
\end{abstract}

Kata kunci: reka bentuk eksperimen, polimer konduktif, jumlah hasil, saiz zarah, kekonduksian

\section{Introduction}

Conducting polymers, such as polyaniline (PAni), polypyrrole (PPy), and polythiophene (PTh), have found many industrial applications due to their unique characteristics, such as the dual function of ionic and electronic conductivity, large surface area and good mechanical properties [1-4]. Among the conductive polymers, PPy has attracted much attention because of its high conductivity [5], good environmental stability [6], electrocatalytic activity [7] and ease of synthesis [8]. Therefore, it has been widely used in electrochemical applications (e.g., as an 


\section{Rika et al: EFFECT OF PROCESS PARAMETERS ON THE SYNTHESIS OF POLYPYRROLE BY THE TAGUCHI METHOD}

electrode material, in electrochemical energy storage [9], as a catalyst support in fuel cells [10], in supercapacitors [11] and in solar cells [12].

Polypyrrole can be synthesized by an electrochemical method [13], chemical oxidative polymerization [14], the reactive self-degradation template method [15], and micro emulsion polymerization [16]. Among the methods of PPy synthesis, the chemical oxidative polymerization method is extensively used because it is cheap, fast, and easy to scale up [17]. Several parameters have been reported to influence the chemical polymerization of PPy such as temperature, polymerization time [18], oxidant species [19], dopant type and dopant concentration [20]. However, prior studies have only examined the effect of one parameter individually and kept the other parameters constant. The Design of Experiments (DOE) method can be used to simultaneously evaluate the parameters for the synthesis of PPy, and this design also reduces the number of experiments.

An experimental design using the Taguchi approach has been implemented by numerous investigators to study the effect of different parameters on the synthesis of polymer particles. For example, a study by Hajian et al. [12] applied the Taguchi method to investigate several factors in the synthesis of polyvinyl butyral. Another study by Shahbazian et al. [1] reported the influence of five operating variables on the polymerization of vinyl chloride using the Taguchi method. The variables studied were temperature, water to monomer weight ratio, concentration of initiator and emulsifier, and agitation speed. The effect of each factor was comprehensively discussed, and the relative optimum condition was also determined. Ashassi-Sorkhabi and Bagheri [21] applied the Taguchi method to optimize the factors affecting the sonoelectrochemical synthesis of the PPy-SiN nanocomposite. The factors investigated were current density, synthesis time and amount of nanoparticles.

In this study, the Taguchi method was used to investigate the effects of (A) oxidant type, (B) molar ratio of oxidant:pyrrole, (C) time and (D) dopant concentration on the chemical synthesis of PPy. The response variables observed included the yield, particle size and conductivity.

\section{Materials and Methods}

The synthesis of PPy was carried out using the chemical oxidative polymerization method [22]. A certain amount of TsOH was added to $100 \mathrm{~mL}$ double-distilled water in a $250 \mathrm{~mL}$ round-bottom flask and stirred for $15 \mathrm{~min}$. Fresh pyrrole $(1.0 \mathrm{~mL}, 14.4 \mathrm{mmol})$ was added to the above solution, and the mixture was stirred for $45 \mathrm{~min}$ at room temperature to obtain a dark solution. An oxidant was added dropwise to the above mixture. Then, the mixture was stirred for a certain amount of time. The black products were filtered and washed repeatedly with ethanol and distilled water until the filtrate was colourless, and then the products were dried under vacuum at room temperature for $24 \mathrm{~h}$.

The particle size of the samples was obtained using a particle sizer analyzer (Malvern Zeta sizer, model Nano zs/ZEN 3600). The conductivity of the samples was measured using Electrochemical Impedance Spectroscopy (EIS) over a frequency range of $10^{2}$ to $10^{4} \mathrm{~Hz}$ with $10 \mathrm{mv}$ at room temperature using a two point probe cell. The morphologies and chemical composition of the samples were characterized using Field Emission Scanning Electron Microscopy (FE-SEM) coupled with Energy Dispersive X-Ray Spectroscopy (EDX) (ZEISS, Germany).

In this work, a Taguchi $\mathrm{L}_{9}$ orthogonal array was used to study the effect of different parameters and determine the optimal conditions. Four factors at three levels were used in this design of experiment, as presented in Table 1 and Table 2, respectively. The response variables observed were yield, particle size and conductivity. 
Table 1. Parameters and levels used in this experiment

\begin{tabular}{llccc}
\hline \multirow{2}{*}{ Parameters } & \multicolumn{3}{c}{ Levels } \\
\cline { 3 - 5 } & $\mathbf{1}$ & $\mathbf{2}$ & $\mathbf{3}$ \\
\hline A & Oxidant type & APS & $\mathrm{FeCl}_{3}$ & $\mathrm{H}_{2} \mathrm{O}_{2}$ \\
B & Molar ratio of oxidant: pyrrole & $1: 1$ & $3: 1$ & $5: 1$ \\
C & Time (h) & 1 & 8 & 24 \\
D & Dopant concentration (M) & 0.01 & 0.05 & 0.1 \\
\hline
\end{tabular}

Table 2. Experimental layout using a $\mathrm{L}_{9}$ orthogonal array

\begin{tabular}{lcccc}
\hline Exp. No. & $\begin{array}{c}\text { A } \\
\text { Oxidant type }\end{array}$ & $\begin{array}{c}\text { B } \\
\text { Molar ratio }\end{array}$ & $\begin{array}{c}\text { C } \\
\text { Time (h) }\end{array}$ & $\begin{array}{c}\text { D } \\
\text { Dopant concentration (M) }\end{array}$ \\
\hline 1 & 1 & 1 & 1 & 1 \\
2 & 1 & 2 & 2 & 2 \\
3 & 1 & 3 & 3 & 3 \\
4 & 2 & 1 & 2 & 3 \\
5 & 2 & 2 & 3 & 1 \\
6 & 2 & 3 & 1 & 2 \\
7 & 3 & 1 & 3 & 2 \\
8 & 3 & 2 & 1 & 3 \\
9 & 3 & 3 & 2 & 1 \\
\hline
\end{tabular}

The S/N (signal-to-noise) is a quality indicator that is used to evaluate the effect of changing particular parameter on the process performance. Generally, there are three categories of performance characteristics in the analysis of the $\mathrm{S} / \mathrm{N}$ ratio [23-26].

Type $\mathrm{S}$ (smaller is better):

$$
\mathrm{S} / \mathrm{N}_{\mathrm{S}}=-10 \log \left[\frac{\sum_{i=1}^{n}\left(y i^{2}\right)}{n}\right]
$$

Type B (Bigger is better):

$$
\mathrm{S} / \mathrm{N}_{\mathrm{B}}=-10 \log \left[\frac{\sum_{i=1}^{n}\left(\frac{1}{y^{2}}\right)}{n}\right]
$$

and Type $\mathrm{N}$ (nominal is better):

$$
\mathrm{S} / \mathrm{N}_{\mathrm{N}}=10 \log \frac{\left(\frac{1}{n}\right)\left(\left(\left(\sum_{i=1}^{n} y i\right)^{2} / n\right)-\left(\sum_{i=1}^{n} y i^{2}-\left(\left(\sum_{i=1}^{n} y i\right)^{2} / n\right) / n-1\right)\right)}{\left(\sum_{i=1}^{n} y i^{2}-\left(\left(\sum_{i=1}^{n} y i\right)^{2} / n\right) / n-1\right.}
$$

where $n$ is the number of replicates and $y i$ is the response variable at $(i=n)$.

In this study, the $\mathrm{S} / \mathrm{N}$ ratio was selected according to the criterion that smaller is better for particle size and bigger is better for both yield and electronic conductivity. 
Rika et al: EFFECT OF PROCESS PARAMETERS ON THE SYNTHESIS OF POLYPYRROLE BY THE TAGUCHI METHOD

\section{Morphology of the polypyrrole particles}

\section{Results and Discussion}

The FE-SEM morphology for the PPy particles obtained in this experiment was presented in Figure 1. As shown in Figure 1, all the PPy particles exhibited agglomerates of various sizes depending on the synthesis parameters.

Table 3 shows the chemical composition of the PPy particles as obtained by EDAX. The results confirmed that the presence of sulfur originated from the dopant (TSOH). The presence of chlorine and iron elements from experiments no. 4 to no. 6 may come from $\mathrm{FeCl}_{3}$, which was doped into the PPy/TSOH particles as the oxidant.
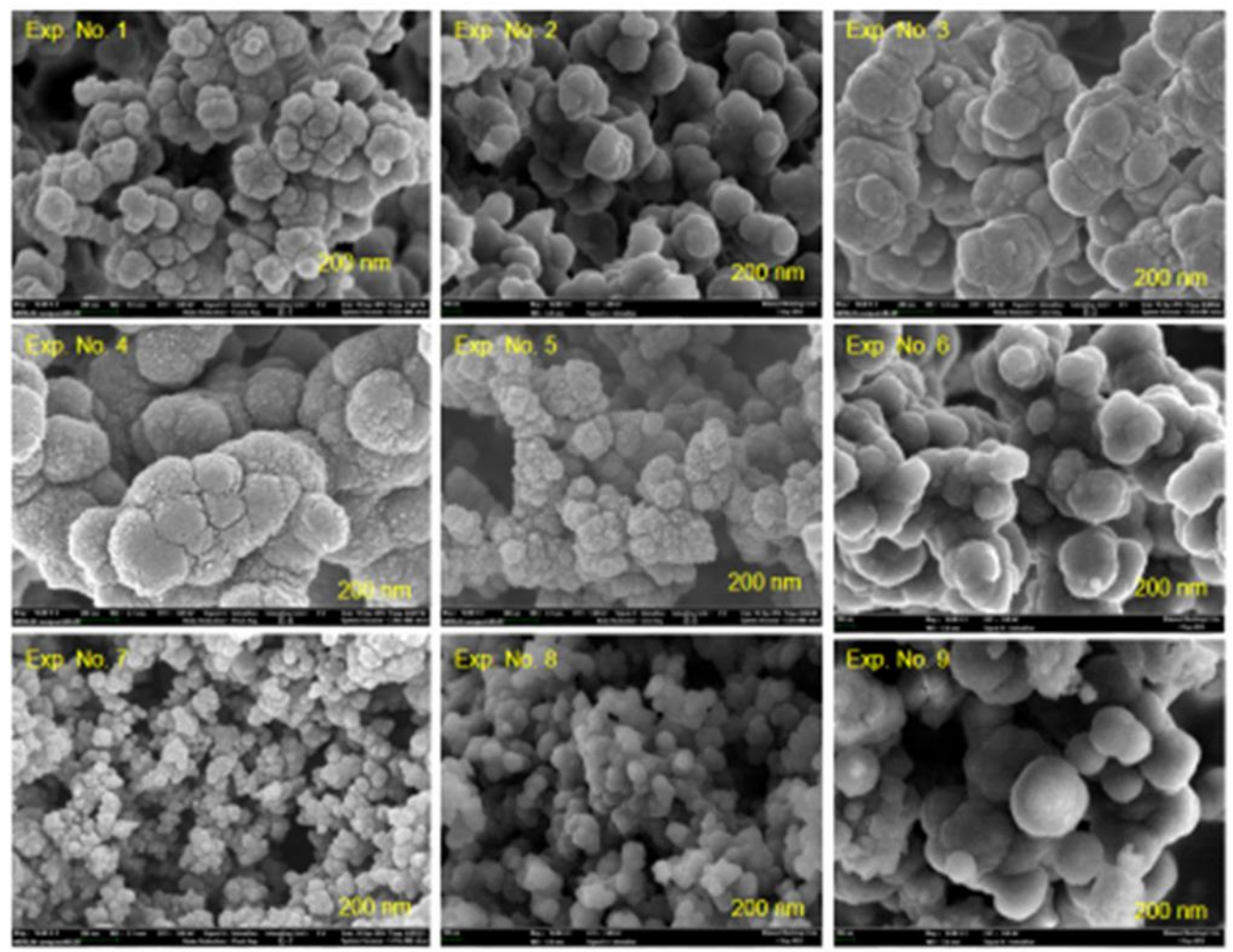

Figure 1. FESEM images of the samples

Table 3. Chemical composition in weight percent as obtained by EDAX

\begin{tabular}{ccccccc}
\hline \multirow{2}{*}{ Experiment } & \multicolumn{7}{c}{ Weight $(\%)$} \\
\cline { 2 - 7 } & $\mathbf{C}$ & $\mathbf{N}$ & $\mathbf{O}$ & $\mathbf{S}$ & $\mathbf{C l}$ & $\mathbf{F e}$ \\
\hline 1 & 68.24 & 8.67 & 20.32 & 2.77 & - & - \\
2 & 61.98 & 14.04 & 18.97 & 5.00 & - & - \\
3 & 75.47 & 1.71 & 13.91 & 8.90 & - & - \\
4 & 63.39 & 14.44 & 16.37 & 3.56 & 1.86 & 0.18 \\
5 & 72.17 & 1.54 & 20.31 & 3.64 & 1.90 & 0.44 \\
6 & 70.96 & 2.54 & 11.94 & 6.78 & 3.66 & 4.11 \\
7 & 60.87 & 13.03 & 22.10 & 4.01 & - & - \\
8 & 66.65 & 0.70 & 31.95 & 0.70 & - & - \\
9 & 60.76 & 12.65 & 22.19 & 4.41 & - & - \\
\hline
\end{tabular}




\section{Taguchi experimental design analysis}

The Taguchi method was used to identify the optimal conditions and to select parameters that have the most influence on the yield, particle size and electronic conductivity of polypyrrole. The results of the measurement and $\mathrm{S} / \mathrm{N}$ ratio values of the Taguchi method are shown in Table 4. As shown in Table 4, the smallest particle size $(0.394$ $\mu \mathrm{m})$ was found in experiment no. 1 , whereas the highest yield $(0.69 \mathrm{~g})$ and electronic conductivity $(0.730 \mathrm{~S} / \mathrm{cm})$ were found in experiments no. 3 and no. 6 , respectively.

Table 4. Experimental measured value and $\mathrm{S} / \mathrm{N}$ ratio for yield, particle size and electronic conductivity of polypyrrole particles

\begin{tabular}{ccccccc}
\hline \multirow{2}{*}{ No. } & \multicolumn{2}{c}{ Yield } & \multicolumn{2}{c}{ Particle Size } & \multicolumn{2}{c}{ Electronic conductivity } \\
\cline { 2 - 7 } & $\begin{array}{c}\text { Raw data } \\
(\mathbf{g})\end{array}$ & $\begin{array}{c}\text { S/N ratio } \\
(\mathbf{d B})\end{array}$ & $\begin{array}{c}\text { Raw data } \\
(\boldsymbol{\mu} \mathbf{\text { m}})\end{array}$ & $\begin{array}{c}\text { S/N ratio } \\
(\mathbf{d B})\end{array}$ & $\begin{array}{c}\text { Raw data } \\
(\mathbf{S} / \mathbf{c m})\end{array}$ & $\begin{array}{c}\text { S/N ratio } \\
(\mathbf{d B})\end{array}$ \\
\hline 1 & 0.09 & -20.92 & 0.394 & 8.09 & 0.085 & -21.41 \\
2 & 0.34 & -9.37 & 0.481 & 6.36 & 0.270 & -11.37 \\
3 & 0.69 & -3.22 & 0.675 & 3.42 & 0.043 & -27.33 \\
4 & 0.07 & -23.10 & 1.574 & -3.94 & 0.660 & -3.61 \\
5 & 0.22 & -13.15 & 0.430 & 7.33 & 0.230 & -12.77 \\
6 & 0.43 & -7.33 & 0.772 & 2.25 & 0.730 & -2.73 \\
7 & 0.01 & -40.00 & 0.965 & 0.31 & 0.014 & -37.08 \\
8 & 0.20 & -13.98 & 0.675 & 3.41 & 0.029 & -30.75 \\
9 & 0.49 & -6.20 & 1.059 & 0.50 & 0.030 & -30.46 \\
\hline
\end{tabular}

The mean S/N ratio for each parameter level is summarized in Table 5. As shown in Table 5, the molar ratio of oxidant: pyrrole $(76.91 \%)$ has the highest value for yield and the oxidant type $(82.62 \%)$ has the highest value for electronic conductivity. Therefore, it can be concluded that the molar ratio of oxidant: pyrrole and oxidant type are the parameters that are significant and affect the yield and electronic conductivity, respectively. In contrast, all the parameters were found almost equally to affect the particle size (Table 5).

Table 5. Mean S/N ratio for yield, particle size, and electronic conductivity

\begin{tabular}{lcccc}
\hline \multicolumn{1}{c}{$\begin{array}{c}\text { Factor } \\
\text { Parameter }\end{array}$} & $\begin{array}{c}\text { A } \\
\text { Oxidant type }\end{array}$ & $\begin{array}{c}\text { B } \\
\text { Molar ratio }\end{array}$ & $\begin{array}{c}\text { C } \\
\text { Time }\end{array}$ & $\begin{array}{c}\text { D } \\
\text { Dopant concentration }\end{array}$ \\
\hline Yield & & & & \\
Level 1 (dB) & -11.17 & -28.00 & -14.08 & -13.42 \\
Level 2 (dB) & -14.53 & -12.17 & -12.89 & -18.90 \\
Level 3 (dB) & -20.06 & -5.58 & -18.79 & -13.43 \\
$\rho(\%)$ & 11.67 & 76.91 & 5.65 & 5.78 \\
Particle Size & & & & \\
Level 1 (dB) & 5.96 & 1.49 & 4.58 & 5.31 \\
Level 2 (dB) & 1.88 & 5.70 & 0.97 & 2.98 \\
Level 3 (dB) & 1.41 & 2.06 & 3.69 & 0.96 \\
$\rho(\%)$ & 31.67 & 26.49 & 17.88 & 23.95 \\
Electronic Conductivity & & & & \\
Level 1 (dB) & -20.04 & -20.70 & -18.30 & -21.54 \\
Level 2 (dB) & -6.37 & -18.30 & -15.15 & -17.06 \\
Level 3 (dB) & -32.76 & -20.17 & -25.72 & -20.56 \\
$\rho(\%)$ & 82.62 & 0.76 & 13.99 & 2.63 \\
\hline
\end{tabular}




\section{Rika et al: EFFECT OF PROCESS PARAMETERS ON THE SYNTHESIS OF POLYPYRROLE BY THE TAGUCHI METHOD}

Figure 2 displays the graphs for (a) yield, (b) particle size and (c) electronic conductivity. As shown in Figure 2 (a), the optimum levels for each of the parameters are A1, B3, C3, and D3. Therefore, based on the graph, the optimum conditions for maximizing the yield are an oxidant type of APS, a molar ratio of oxidant:pyrrole of 5:1, a polymerization time of 24 hours and a dopant concentration of $0.1 \mathrm{M}$. Figure 2 (b) displays the optimum levels for decreasing particle size, which are as follows: A1, B2, C1, and D1, i.e., an oxidant type of APS, a molar ratio of oxidant: pyrrole of 3:1, a polymerization time of 1 hour and a dopant concentration of $0.01 \mathrm{M}$. Finally, to maximize the electronic conductivity (Figure 2 (c)), the optimum conditions are at A2, B3, C2, and D2, i.e., an oxidant type of $\mathrm{FeCl}_{3}$, a molar ratio of oxidant: pyrrole of 5:1, a polymerization time of 8 hours and a dopant concentration of 0.05 M.
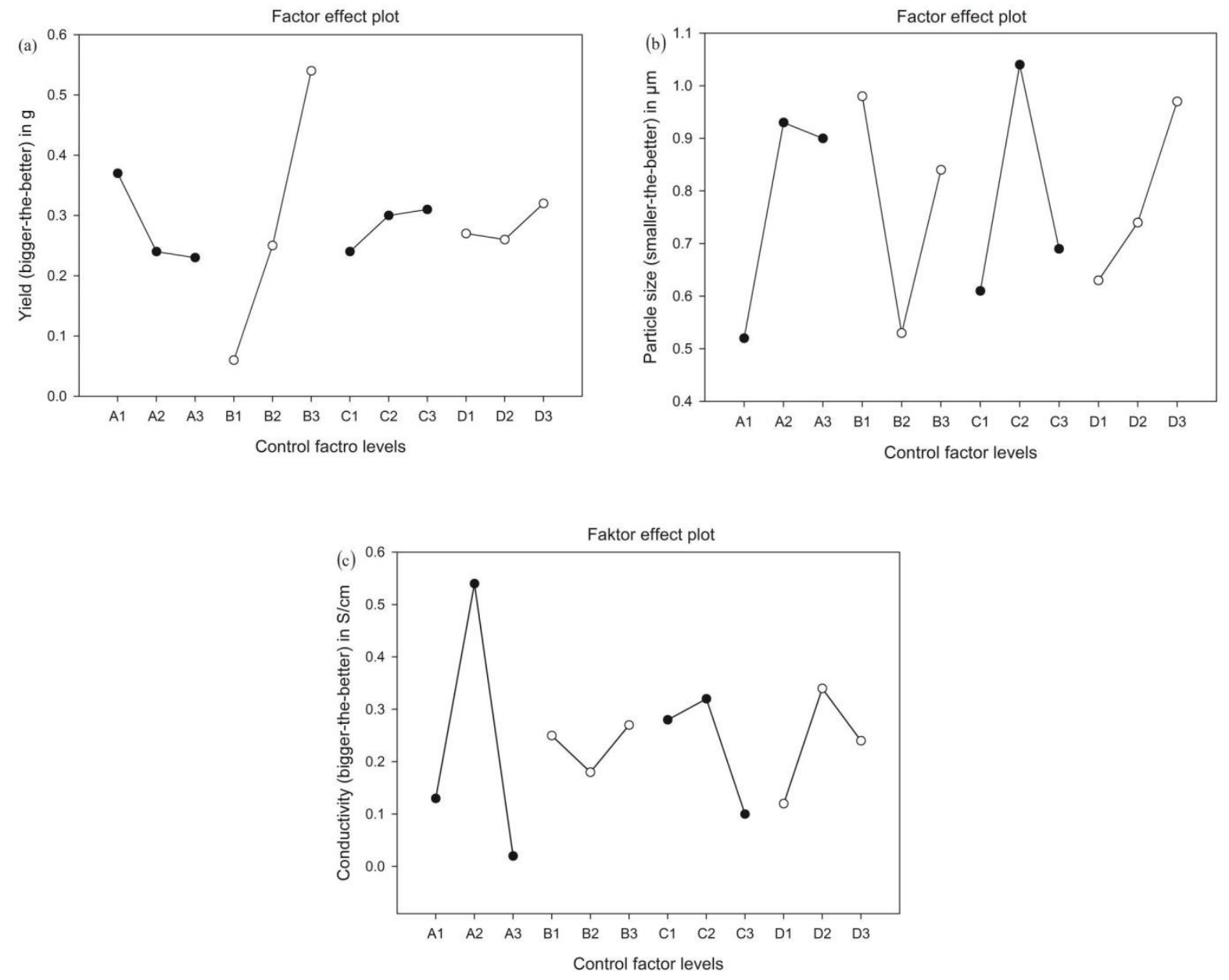

Figure 2. Graph for (a) yield, (b) particle size, and (c) electronic conductivity

In addition to $\mathrm{S} / \mathrm{N}$ ratio, the variance analysis (ANOVA) was performed to investigate which process parameters significantly affect the response variables. The results of the ANOVA for yield, particle size and electronic 
conductivity are presented in Table 6. As shown in Table 6, the order of significance of the factors for yield is as follows: $\mathrm{B}>\mathrm{A}>\mathrm{D}>\mathrm{C}$, whereas for particle size and electronic conductivity the order is: $\mathrm{A}>\mathrm{B}>\mathrm{D}>\mathrm{C}$ and $\mathrm{A}>\mathrm{C}>$ $\mathrm{D}>\mathrm{B}$, respectively.

Table 6. The ANOVA table of yield, particle size, and electronic conductivity for selected factorial model

\begin{tabular}{lcccccccccccc}
\hline Factor & \multicolumn{4}{c}{ Yield } & \multicolumn{4}{c}{ Particle size } & \multicolumn{3}{c}{ Electronic conductivity } \\
\cline { 2 - 14 } & $\boldsymbol{S}$ & $\boldsymbol{\phi}$ & $\boldsymbol{V}$ & $\boldsymbol{F}$ & $\boldsymbol{S}$ & $\boldsymbol{\phi}$ & $\boldsymbol{V}$ & $\boldsymbol{F}$ & $\boldsymbol{S}$ & $\boldsymbol{\phi}$ & $\boldsymbol{V}$ & $\boldsymbol{F}$ \\
\hline A & 121 & 2 & 60 & 6 & 38 & 2 & 19 & 16 & 1045 & 2 & 523 & 41 \\
B & 797 & 2 & 398 & 38 & 31 & 2 & 16 & 13 & 10 & 2 & 5 & 0 \\
C & 59 & 2 & 29 & 3 & 21 & 2 & 11 & 9 & 177 & 2 & 88 & 7 \\
D & 60 & 2 & 30 & 3 & 28 & 2 & 14 & 12 & 33 & 2 & 17 & 1 \\
& & & & & & & & & & & & \\
Total & 1036 & 8 & & & 119 & 8 & & & 1265 & 8 & & \\
\hline
\end{tabular}

Additional experiments at level A2, B3, C1, and D2 were conducted to confirm the Taguchi method. The results of the experiments as well as the prediction are shown in Table 7. There are good agreements between the predicted and experimental results for the yield, particle size and electronic conductivity. Thus, the synthesis process for the polypyrrole particles can be improved using the Taguchi method.

Table 7. Results of the confirmation for yield, particle size and electronic conductivity

\begin{tabular}{llcccccc}
\hline \multirow{2}{*}{ Level } & \multicolumn{2}{c}{ Yield } & \multicolumn{2}{c}{ Particle size } & \multicolumn{2}{c}{ Electronic conductivity } \\
\cline { 3 - 7 } & & $\begin{array}{c}\text { Yield } \\
(\mathbf{g})\end{array}$ & $\begin{array}{c}\text { S/N ratio } \\
(\mathbf{d B})\end{array}$ & $\begin{array}{c}\text { Particle size } \\
(\boldsymbol{\mu m})\end{array}$ & $\begin{array}{c}\text { S/N ratio } \\
(\mathbf{d B})\end{array}$ & $\begin{array}{c}\text { E. Conductivity } \\
(\mathbf{S} / \mathbf{c m})\end{array}$ & $\begin{array}{c}\text { S/N ratio } \\
(\mathbf{d B})\end{array}$ \\
\hline Prediction & A2B3C1D2 & 0.43 & -7.33 & 0.771 & 2.26 & 0.73 & -2.73 \\
Experiment & A2B3C1D2 & 0.40 & -7.96 & 0.725 & 2.79 & 0.77 & -2.27 \\
\hline
\end{tabular}

Effects of process parameters on the synthesis of the polypyrrole particles

Three types of oxidants were used to study their effects on pyrrole polymerization. All the solid products observed from the different types of oxidants were dark in colour. From the results of the Taguchi analysis shown in Figure 2, when APS was used, the products obtained the highest yield $(0.37 \mathrm{~g})$ and smallest particle size $(0.52 \mu \mathrm{m})$, whereas when $\mathrm{FeCl}_{3}$ was used, the highest conductivity $(0.54 \mathrm{~S} / \mathrm{cm})$ was obtained. When $\mathrm{H}_{2} \mathrm{O}_{2}$ was used as the oxidant, it produced the lowest yield $(0.23 \mathrm{~g})$ and conductivity $(0.02 \mathrm{~S} / \mathrm{cm})$ and the larger particles size $(0.90 \mu \mathrm{m})$. The PPy synthesized using APS as the oxidant produced a higher yield than $\mathrm{FeCl}_{3}$ and $\mathrm{H}_{2} \mathrm{O}_{2}$ because APS has more oxidizability towards the pyrrole monomers than the other oxidants $[19,27]$. The high conductivity obtained with $\mathrm{FeCl}_{3}$ as the oxidant compared to APS and $\mathrm{H}_{2} \mathrm{O}_{2}$ is due to the presence of iron ions. This result is in agreement with the previous work by Lascelles et al. [28]. They also found that the synthesis of polypyrrole silica particles using $\mathrm{FeCl}_{3} \cdot 6 \mathrm{H}_{2} \mathrm{O}$ produces a significantly higher conductivity than $\left(\mathrm{NH}_{4}\right)_{2} \mathrm{~S}_{2} \mathrm{O}_{8}$ and $\mathrm{H}_{2} \mathrm{O}_{2}$.

The effects of the molar ratio of oxidant to pyrrole on the yield, particle size and electronic conductivity are shown in Figure 2 (a-c). The product yield increased from $0.06 \mathrm{~g}$ to $0.54 \mathrm{~g}$ as the molar ratios of oxidant to pyrrole increased from 1:1 to 5:1. The same observation was also found by Li et al. [27] for the polymerization of PPy using APS as the oxidant. They also noted that the amount of oxidant required to produce sufficient PPy particles is at least equal to the monomer (molar ratio of oxidant/monomer higher than 1). From Figure 2 (b), when the molar ratios increased from 1:1 to 5:1, the particle size of PPy decreased first from $0.98 \mu \mathrm{m}$ to $0.53 \mu \mathrm{m}$ and then increased 


\section{Rika et al: EFFECT OF PROCESS PARAMETERS ON THE SYNTHESIS OF POLYPYRROLE BY THE TAGUCHI METHOD}

again $(0.84 \mu \mathrm{m})$. This is consistent with the finding of $\mathrm{Li}$ et al. [27]. They emphasized that at a lower concentration of oxidant, less Py radicals are formed, the polymerization process is slow, and thus smaller particles are formed. When the oxidant concentration is too high, more monomers are oxidized into radicals, and the particle size increases. The amount of oxidant also influenced the electronic conductivity of the PPy. Figure 2 shows that as the molar ratio increased from $1: 1$ to $5: 1$, the conductivity decreased first from $0.25 \mathrm{~S} / \mathrm{cm}$ to $0.18 \mathrm{~S} / \mathrm{cm}$ and then increased with a maximum of $0.27 \mathrm{~S} / \mathrm{cm}$ at a molar ratio of 5:1.

Figure 2 also shows the influence of polymerization time on the synthesis of the PPy particles. The yield of the PPy particles increased from $0.24 \mathrm{~g}$ to $0.31 \mathrm{~g}$ when the polymerization time increased from 1 to $24 \mathrm{~h}$. The same trend were also observed by Omastova et al. [29] and Pina et al. [11] for the pyrrole polymerization using silver nitrate and gold as the dopant, respectively. From their studies, the yield increased from $0.394 \mathrm{~g}$ to $4.939 \mathrm{~g}$ and $1 \%$ to 99 $\%$ when the polymerization time increased from 24 to 168 hours and 8 to 72 hours, respectively. Thus, the longer the reaction time, the more PPy particles formed. Figure 2 also shows that as the polymerization time increased from $1 \mathrm{~h}$ to 24 hours, the particle size increased first from $0.61 \mu \mathrm{m}$ to $1.04 \mu \mathrm{m}$ and then decreased to approximately $0.69 \mu \mathrm{m}$, whereas the electronic conductivity increased from $0.28 \mathrm{~S} / \mathrm{cm}$ to $0.32 \mathrm{~S} / \mathrm{cm}$ and decreased after a polymerization time of 24 hours $(0.10 \mathrm{~S} / \mathrm{cm})$.

When $\mathrm{TsOH}$ as a dopant into the polymerization was introduced, the yield increased from $0.27 \mathrm{~g}$ to $0.32 \mathrm{~g}$ as the dopant concentration increased. This is because the $\mathrm{TsOH}$ acted as both dopant and template at the higher concentration. Upadhyay and Kumar [15] showed that the yield of the sample increased from $43.12 \%$ to $58.63 \%$ with an increase in CTAB (dopant) concentration from $1 \mathrm{mM}$ to $3 \mathrm{mM}$. They also observed that the particle size increased from $0.63 \mu \mathrm{m}$ to $0.97 \mu \mathrm{m}$ when the concentration of dopant (TsOH) increased. However, the conductivity of the PPy particles was found to increase from $0.12 \mathrm{~S} / \mathrm{cm}$ to $0.34 \mathrm{~S} / \mathrm{cm}$ when the dopant concentration was increased from $0.01 \mathrm{M}$ to $0.05 \mathrm{M}$. Upon further increase in the dopant concentration, the conductivity decreased to $0.24 \mathrm{~S} / \mathrm{cm}$. Yang and Liu [30] observed a similar trend for the polymerization of PPy with the addition of PHMPS as the dopant. Their results showed that the conductivity of the samples increased when the feeding ratio of PHMPS was increased from 1 to $10 \mathrm{wt} \%$ and subsequently decreased. Several other investigators also reported the same observation $[14-15,22,31]$.

\section{Conclusion}

In this study, an orthogonal Taguchi L9 array was used to investigate the effects of the synthesis parameters on the polymerization of pyrrole. The parameters studied were oxidant type, molar ratio of oxidant: pyrrole, time and dopant concentration. The results showed that the molar ratio of oxidant: pyrrole and the oxidant type significantly affected the yield and electronic conductivity, respectively. As the molar ratios of oxidant to pyrrole increased from 1:1 to 5:1, the product yield also increased from $0.06 \mathrm{~g}$ to $0.54 \mathrm{~g}$. Additionally, when using $\mathrm{FeCl}_{3}$ as the oxidant, the highest conductivity $(0.54 \mathrm{~S} / \mathrm{cm})$ was obtained compared with APS and $\mathrm{H}_{2} \mathrm{O}_{2}$.

\section{Acknowledgement}

This work was supported by the Universiti Kebangsaan Malaysia and the Malaysia Ministry of Higher Education (MOHE) with research grants of GGPM-2013-044, DIP-2014-002 and FRGS/2/2013/UKM/02/3.

\section{References}

1. Shahbazian, A., Navarchian, A. H. and Pourmehr, M. (2009). Application of Taguchi method to investigate the effects of process factors on the performance of batch emulsion polymerization of vinyl chloride. Journal of Applied Polymer Science, 113 (5): 2739-2746.

2. Al-Dulaimi, A. A., Hashim, S. and Khan, M. (2011). Corrosion protection of carbon steel using polyaniline composite with inorganic pigments. Sains Malaysiana, 40 (7): 757-763.

3. Izzuddin, I., Jumali, M. H. H., Yahaya, M. and Salleh, M. M. (2012). New hybridization approach of titanium organometallic: PANI thin films as room temperature gas sensors. Sains Malaysiana, 41 (8): 1017-1021.

4. Juamli, M. H. H., Ramli, N., Izzuddin, I., Salleh M. M. and Yahaya, M. (2011). Influence of PANI additions on methanol sensing properties of ZnO thin films. Sains Malaysiana, 40 (3): 203-208. 
5. Khan, A. A. and Paquiza, L. (2011). Electrical behavior of conducting polymer based 'polymericinorganic'nanocomposite: Polyaniline and polypyrrole zirconium titanium phosphate. Synthetic Metals, 161 (9): 899-905.

6. Qi, K., Qiu, Y., Chen, Z. and Guo, X. (2012). Corrosion of conductive polypyrrole: Effects of environmental factors, electrochemical stimulation, and doping anions. Corrosion Science, 60: 50-58.

7. Ghamouss, F., Brugère, A., Anbalagan, A. C., Schmaltz, B., Luais, E. and Tran-Van, F. (2013). Novel glycerol assisted synthesis of polypyrrole nanospheres and its electrochemical properties. Synthetic Metals, 168: 9-15.

8. Kim, D. K., Oh, K. W., Ahn, H. J. and Kim, S. H. (2008). Synthesis and characterization of polypyrrole rod doped with p-toluenesulfonic acid via micelle formation. Journal of Applied Polymer Science, 107 (6): 3925 3932.

9. Karaca, E., Pekmez, N. Ö. and Pekmez, K. (2014). Galvanostatic deposition of polypyrrole in the presence of tartaric acid for electrochemical supercapacitor. Electrochimica Acta, 147: 545-556.

10. Yuan, X., Ding, X.-L., Wang, C.-Y. and Ma, Z.-F. (2013). Use of polypyrrole in catalysts for low temperature fuel cells. Energy \& Environmental Science, 6 (4): 1105-1124.

11. Pina, C. D., Falletta, E., Faro, M. L., Pasta, M. and Rossi, M. (2009). Gold-catalysed synthesis of polypyrrole. Gold Bulletin, 42 (1): 27-33.

12. Hajian, M., Koohmareh, G. A. and Rastgoo, M. (2010). Investigation of factors affecting synthesis of polyvinyl butyral by Taguchi method. Journal of Applied Polymer Science, 115 (6): 3592-3597.

13. Tam, P. D. and Hieu, N. V. (2011). Conducting polymer film-based immunosensors using carbon nanotube/antibodies doped polypyrrole. Applied Surface Science, 257 (23): 9817-9824.

14. Yang, C., Wang, X., Wang, Y. and Liu, P. (2012). Polypyrrole nanoparticles with high dispersion stability via chemical oxidative polymerization in presence of an anionic-non-ionic bifunctional polymeric surfactant. Powder Technology, 217: 134-139.

15. Upadhyay, J. and Kumar, A. (2013). Structural, thermal and dielectric studies of polypyrrole nanotubes synthesized by reactive self degrade template method. Materials Science and Engineering: B, 178 (15): $982-$ 989.

16. Hazarika, J. and Kumar, A. (2013). Controllable synthesis and characterization of polypyrrole nanoparticles in sodium dodecylsulphate (SDS) micellar solutions. Synthetic Metals, 175: 155-162.

17. Yuan, X., Kong, H.-C., He, Y.-J., Ma, Z.-F., Yang, Y. and Li, Q. (2014). Effects of composition on electrochemical properties of a non-precious metal catalyst towards oxygen reduction reaction. International Journal of Hydrogen Energy, 39 (28): 16006-16014.

18. Karami, H. and Nezhad, A. R. (2013). Investigation of pulse-electropolymerization of conductive polypyrrole nanostructures. International Journal of Electrochemical Science, 8: 8905-8921.

19. Liao, Y., Wang, X., Qian, W., Li, Y., Li, X. and Yu, D.-G. (2012). Bulk synthesis, optimization, and characterization of highly dispersible polypyrrole nanoparticles toward protein separation using nanocomposite membranes. Journal of Colloid and Interface Science, 386 (1): 148-157.

20. Paramo-García, U., Ibanez, J. \& Batina, N. (2013). AFM analysis of polypyrrole films synthesized in the presence of selected doping agents. International Journal of Electrochemical Science, 8: 2656-2669.

21. Ashassi-Sorkhabi, H. and Bagheri, R. (2014). Sonoelectrochemical synthesis, optimized by Taguchi method, and corrosion behavior of polypyrrole-silicon nitride nanocomposite on St-12 steel. Synthetic Metals, 195: 1-8.

22. Wang, Y., Yang, C. and Liu, P. (2011). Acid blue AS doped polypyrrole (PPy/AS) nanomaterials with different morphologies as electrode materials for supercapacitors. Chemical Engineering Journal, 172 (2-3): 1137-1144.

23. Hung, S.-L., Wen, T.-C. and Gopalan, A. (2002). Application of statistical design strategies to optimize the conductivity of electrosynthesized polypyrrole. Materials Letters, 55 (3): 165-170.

24. Taguchi, G. (1990). Introduction to Quality Engineering: Designing Quality into Products and Processes, Asian Productivity Organization, Tokyo.

25. Bendell, A., Disney, J. \& Pridmore, W. A. (1989). Taguchi Methods: Applications in World Industry. IFS Publications, UK.

26. Taguchi, G. (1962). Tables of orthogonal arrays and linear graphs. Maruzen, Tokyo.

27. Li, X.-G., Li, A., Huang, M.-R., Liao, Y. and Lu, Y.-G. (2010). Efficient and scalable synthesis of pure polypyrrole nanoparticles applicable for advanced nanocomposites and carbon nanoparticles. The Journal of Physical Chemistry C, 114 (45): 19244-19255. 
Rika et al: EFFECT OF PROCESS PARAMETERS ON THE SYNTHESIS OF POLYPYRROLE BY THE TAGUCHI METHOD

28. Lascelles, S., McCarthy, G., Butterworth, M. and Armes, S. (1998). Effect of synthesis parameters on the particle size, composition and colloid stability of polypyrrole-silica nanocomposite particles. Colloid and Polymer Science, 276 (10): 893-902.

29. Omastová, M., Mosnáčková, K., Fedorko, P., Trchová, M. and Stejskal, J. (2013). Polypyrrole/silver composites prepared by single-step synthesis. Synthetic Metals, 166: 57-62.

30. Yang, C. and Liu, P. (2010). Water-dispersed polypyrrole nanoparticles via chemical oxidative polymerization in the presence of a functional polyanion. Reactive and Functional Polymers, 70 (10): 726-731.

31. Wang, X., Yang, C., Li, H. and Liu, P. (2013). Synthesis and electrochemical performance of well-defined flake-shaped sulfonated graphene/polypyrrole composites via facile in situ doping polymerization. Electrochimica Acta, 111: 729-737. 